\title{
Correction to: Improving Institutional Evaluation Methods: Comparing Three Evaluations Using PSM, Exact and Coarsened Exact Matching
}

\author{
Bob Blankenberger ${ }^{1}$ (D) . Sophia Gehlhausen Anderson ${ }^{2,3} \cdot$ Eric Lichtenberger $^{2}$
}

Published online: 16 June 2021

(C) The Author(s) 2021

\section{Correction to: Research in Higher Education https://doi.org/10.1007/s11162-021-09632-0}

The article "Improving Institutional Evaluation Methods: Comparing Three Evaluations Using PSM, Exact and Coarsened Exact Matching", written by Bob Blankenberger, Sophia Gehlhausen Anderson, Eric Lichtenberger, was originally published electronically on the publisher's internet portal on 10 April 2021 without open access. With the author(s)' decision to opt for Open Choice the copyright of the article changed on 1 June 2021 to (C) The Author(s) 2020 and the article is forthwith distributed under a Creative Commons Attribution 4.0 International License, which permits use, sharing, adaptation, distribution and reproduction in any medium or format, as long as you give appropriate credit to the original author(s) and the source, provide a link to the Creative Commons licence, and indicate if changes were made. The images or other third party material in this article are included in the article's Creative Commons licence, unless indicated otherwise in a credit line to the material. If material is not included in the article's Creative Commons licence and your intended use is not permitted by statutory regulation or exceeds the permitted use, you will need to obtain permission directly from the copyright holder. To view a copy of this licence, visit http://creativecommons.org/licenses/by/4.0.

The original article has been corrected.

Open Access This article is licensed under a Creative Commons Attribution 4.0 International License, which permits use, sharing, adaptation, distribution and reproduction in any medium or format, as long as you give appropriate credit to the original author(s) and the source, provide a link to the Creative Commons

The original article can be found online at https://doi.org/10.1007/s11162-021-09632-0.

Bob Blankenberger

rblan2@uis.edu

1 Public Administration, University of Illinois at Springfield, One University Plaza, PAC 421, Springfield, IL 62703, USA

2 Illinois Board of Higher Education, Springfield, USA

3 University of Illinois at Springfield, Springfield, USA 
licence, and indicate if changes were made. The images or other third party material in this article are included in the article's Creative Commons licence, unless indicated otherwise in a credit line to the material. If material is not included in the article's Creative Commons licence and your intended use is not permitted by statutory regulation or exceeds the permitted use, you will need to obtain permission directly from the copyright holder. To view a copy of this licence, visit http://creativecommons.org/licenses/by/4.0/.

Publisher's Note Springer Nature remains neutral with regard to jurisdictional claims in published maps and institutional affiliations. 